\title{
Potential role of ATM in hepatocyte endocytosis of ApoE- deficient, ApoB48-containing lipoprotein in ApoE-deficient mice
}

\author{
JIANHUA WU $^{1}$, YANHONG XIAO ${ }^{1}$, JUANG LIU ${ }^{1}$, HONG YANG $^{3}$, \\ XIAOMIN DONG ${ }^{2}$, SAN HU ${ }^{1}$, SHANRUI JIN ${ }^{1}$ and DONGFANG WU ${ }^{1}$
}

Departments of ${ }^{1}$ Pharmacy and ${ }^{2}$ Osteology, Zhongnan Hospital of Wuhan University, Wuhan, Hubei 430071, P.R. China;

${ }^{3}$ Department of Cardiovascular Biology, Meharry Medical College, Nashville, TN 37208, USA

Received August 4, 2013; Accepted November 7, 2013

DOI: $10.3892 /$ ijmm.2013.1566

\begin{abstract}
Individuals carrying mutations at both ataxia telangiectasia mutated (ATM) gene alleles reportedly have increased plasma cholesterol and triglyceride levels. Previous studies have demonstrated that defective ATM function promotes atherosclerosis. We previously demonstrated that ATM facilitates the clearance of plasma apolipoprotein (Apo)E-deficient, ApoB48-containing $\left(\mathrm{E}^{-} / \mathrm{B}^{48}\right)$ lipoproteins in ApoE-deficient mice (ApoE $E^{-/-}$mice). However, to date there is no exact explanation available as to the mechanism(s) through which ATM is involved in the removal of $\mathrm{E}^{-} / \mathrm{B}^{48}$ lipoprotein in $A p o E^{-/-}$mice. In this study, to our knowledge, we demonstrate for the first time that heterozygous ATM mutation reduces the hepatocyte uptake of $\mathrm{E}^{-/ \mathrm{B}^{48}}$ lipoproteins in $A p o E^{-/-}$mice; however, heterozygous $A T M$ mutation did not affect hepatocyte binding to $\mathrm{E}^{-} / \mathrm{B}^{48}$ lipoproteins. Moreover, our results revealed that ATM proteins were localized in the nucleus, early endosomes and late endosomes, but not in the plasma membrane in the hepatocytes of $A p o E^{-/-}$mice. In addition, following treatment with the ATM activator, chloroquine, and $\mathrm{E}^{-} / \mathrm{B}^{48}$ lipoproteins, ATM interacted with class III phosphatidylinositol-3-kinases (PI3Ks) and the activated ATM protein enhanced class III PI3K activity. Furthermore, treatment with a class III PI3K inhibitor (LY290042 and 3-MA) attenuated the intracellular total cholesterol accumulation induced by ATM activation. These results provide insight into the mechanisms behind the involvment of ATM in the process of endocytosis of $\mathrm{E}^{-} / \mathrm{B}^{48}$ lipoprotein in $A p o E^{-/-}$mice, demonstrating the role of class III PI3K protein.
\end{abstract}

\section{Introduction}

Patients with ataxia telangiectasia (A-T), carrying mutations at both ataxia telangiectasia mutated $(A T M)$ alleles $\left(A T M^{-/}\right)$,

Correspondence to: Professor Dongfang Wu, Department of Pharmacy, Zhongnan Hospital of Wuhan University, 169 Dong-Hu Road, Wuhan, Hubei 430071, P.R. China

E-mail:dfwu2010@whu.edu.cn

Key words: ataxia telangiectasia mutated, class III phosphatidylinositol-3-kinases, lipoprotein, hepatocytes present with progressive cerebellar ataxia, susceptibility to cancer, immunodeficiency, insulin resistance and hyperglycemia $(1,2)$. In addition, patients with A-T reportedly have increased plasma cholesterol and triglyceride levels (3), which are the two major risk factors for atherosclerosis. It is currently known that humans with the heterozygous $A T M$ mutation $\left(A T M^{+/}\right)$, which account for $0.5-2 \%$ of the total population, also have an increase risk of developing atherosclerosis-related cardiovascular diseases (4). Previous studies have suggested that defective ATM function promotes atherosclerosis through multiple systemic pro-atherosclerotic features, such as metabolic syndrome, oxidative stress, DNA damage and mitochondrial dysfunction $(5,6)$. We have prevoiusly demonstrated that ATM assists the clearance of plasma apolipoprotein (Apo)E-deficient, ApoB48-containing $\left(\mathrm{E}^{-/} \mathrm{B}^{48}\right)$ lipoproteins in ApoE-deficient mice (ApoE ${ }^{-/-}$mice) (7). However, to date, there is no exact explanation available as to the mechanisms through which ATM is involved in the endocytosis or removal of $\mathrm{E} / \mathrm{B}^{48}$ lipoproteins in $A p o E^{-/-}$mice.

It is now known that a fraction of the ATM protein is also present in the cytoplasm and is associated with vesicular structures, such as peroxisomes, lysosomes and endosomes (8-10), which indicates that ATM may be involved in the trafficking of proteins and vesicles. Certain studies have reported that in the absence of ATM, intracellular vesicle and/or protein transport may be impaired, leading to abnormalities in endosomal function (11). Therefore, we hypothesized that ATM mutations in $A p o E^{-/-}$mice may lead to an overaccumulation of plasma ApoB-48-containing lipoproteins, thus promoting the development of atherosclerosis, which may be associated with the loss of or the impaired function of cytosolic ATM protein. This may affect the process of endocytosis of lipoproteins or it may influence lipid metabolism enzymes involved in the endocytic scavenging process, and transport of proteins to the peroxisomes and/or lysosomes.

Phosphatidylinositol-3-kinases (PI3Ks), are known to play a key role in a wide range of cellular functions, including cell growth, proliferation, differentiation, motility and survival (12). It is also evident that PI3Ks play an important role in endocytosis and vesicle transport, including a role in the recruitment of regulatory proteins to the plasma membrane, endocytic uptake and recycling of receptors (13). Class III PI3Ks are responsible for the production of phosphatidylinositol-3-phosphate 
[PtdIns(3)P] (14), which is enriched in the membranes of early endosomes and the internal vesicles of multivesicular bodies $(15,16)$. PtdIns(3)P recruits proteins containing FYVE, PX or PH motifs, and is involved in the control of vesicular transport and intracellular protein sorting $(17,18)$. Certain studies have reported that $\mathrm{PI} 3 \mathrm{Ks}$ are involved in the metabolism of different lipoproteins. For example, Shetty et al (19) demonstrated that PI3K plays an important role in class B type I scavenger receptor subcellular localization and selective lipid uptake in hepatocytes. Kzhyshkowska et al (20) reported that PI3K activity is required for the transfer of stabilin-1 and its ligand, acetylated low-density lipoprotein, from early endosomes to late endosomes. As ATM has been shown to possess a carboxyl-terminal domain homologous to PI3Ks and that the ATM protein regulates PI3K protein activity $(21,22)$, we hypothesized that PI3K may involved in the promotion of $\mathrm{E}^{-} / \mathrm{B}^{48}$ lipoprotein endocytosis by cytoplasmic ATM in the hepatocytes of $A p o E^{-/-}$mice.

In this study, we demonstrate that heterozygous ATM mutation reduces the hepatocyte uptake of $\mathrm{E}^{-/} \mathrm{B}^{48}$ lipoproteins in $\mathrm{ApoE}^{-/-}$mice and that the ATM protein is distributed in early and late endosomes. In addition, we reveal that the activated ATM protein interacts with class III PI3K and affects its activity and that a class III PI3K inhibitor attenuates the intracellular total cholesterol accumulation induced by ATM activation. The data presented in this study, provide insight into the mechanisms behind the involvement of ATM in the process of endocytosis of $\mathrm{E}^{-/} \mathrm{B}^{48}$ lipoproteins.

\section{Materials and methods}

Animals. ATM $^{+/-}$mice were kindly provided by Dr Anthony Wynshaw-Boris (University of California, San Diego, CA, USA). $A p o B^{48 / 48} / A p o E^{-/}$and $129 \mathrm{vEv}$ wild-type mice were obtained from the Jackson Laboratory (Bar Harbor, ME, USA). Apo $B^{48 / 48} /$ ApoE $^{-/-}$mice were obtained by crossbreeding $A p o E^{-/ .}$ mice with $A p o B^{48 / 48}$ mice. $A T M^{+/ /} / A p o E^{-/-}$mice were obtained by crossbreeding $A T M^{+/-}$and $A p o E^{-/-}$mice. In the present study, $A T M^{+/-} / A p o E^{-/}$mice were used at 14 weeks of age. The mice appeared as healthy as their $A T M^{+/+} / A p o E^{-/-}$littermates. All procedures for handling the animals were approved by the Institutional Animal Care and Use Committees of Meharry Medical College (Nashville, TN, USA) and were performed in accordance with the guidelines of the American Association for the Accreditation of Laboratory Animal Care and the National Institutes of Health and Animal Care Guidelines of the Animal Experimental Committee of the College of Medicine, Wuhan University, Wuhan, China.

Hepatocyte isolation and culture. Hepatocytes were isolated from $A p o E^{-/-}$mice. After the mice were anesthetized and the livers exposed, the livers were first perfused with calciumfree buffer for $1.5 \mathrm{~min}$ and then perfused with $0.25 \%(\mathrm{w} / \mathrm{w})$ collagenase type I (nitrogen) at $37^{\circ} \mathrm{C}$ in Williams E nutrient medium for $4 \mathrm{~min}$. Subsequently, the hepatocytes were isolated by gently mincing the livers in Williams E nutrient medium containing $0.25 \%$ collagenase type I, filtered through a nylon gauze, and centrifuged twice for $5 \mathrm{~min}$ at $50 \mathrm{xg}$ at $4^{\circ} \mathrm{C}$. The cell pellets consisted of pure hepatocytes, as confirmed under a light microscope, and the viability of the cells was $90 \%$ as determined by trypan blue exclusion assay.
Preparation of $E^{-} / B^{48}$ lipoproteins. $\mathrm{E}^{-} / \mathrm{B}^{48}$ lipoproteins were prepared from the plasma of $A p o B^{48 / 48} / \mathrm{ApoE}^{-/-}$mice as previously described in the study by Wu et al (7). Briefly, mouse plasma was overlaid with $\mathrm{KBr}$ gradient solution $(\mathrm{d}<1.006)$ and centrifuged at 120,000 rpm for $2 \mathrm{~h}$ with a Sorvall Discovery M150 ultracentrifuge (Thermo Scientific, Waltham, MA, USA). The $\mathrm{E}^{-} / \mathrm{B}^{48}$ lipoproteins were collected, dialyzed in phosphate-buffered saline (PBS) (pH 7.4) containing $10 \mathrm{mM}$ EDTA for $48 \mathrm{~h}$ at $4^{\circ} \mathrm{C}$, and filtered through a $0.45 \mu \mathrm{m}$ filter. One milliliter of $\mathrm{E}^{-/} \mathrm{B}^{48}$ lipoproteins at a concentration of $1 \mathrm{mg} / \mathrm{ml}$ was mixed with $0.2 \mathrm{ml}$ of $1 \mathrm{M}$ glycine buffer in $0.25 \mathrm{M} \mathrm{NaOH}$ (pH 10) and then mixed with a solution containing $7 \mu \mathrm{l}$ of $100 \mathrm{mM}$ iodine monochloride, $7 \mu \mathrm{l}$ of $100 \mu \mathrm{Ci} / \mu \mathrm{l}^{125} \mathrm{I}$, and $25 \mu \mathrm{l}$ of $1 \mathrm{M}$ glycine buffer in $0.25 \mathrm{M} \mathrm{NaOH}$ (pH 10). Subsequently, the reaction mixture was incubated at room temperature for 10 min and then applied to a 10 DG chromatography column (Bio-Rad Laboratories, Hercules, CA, USA) to remove free iodine. The ${ }^{125} \mathrm{I}$-labeled $\mathrm{E}^{-} / \mathrm{B}^{48}$ lipoproteins were eluted with PBS (pH 7.4) and dialyzed extensively against PBS (pH 7.4).

Binding and uptake assays. For the uptake experiments, the cells were washed twice with $2 \mathrm{ml}$ of serum-free medium, containing $0.2 \% \mathrm{BSA}$. The cells were then incubated with $1 \mathrm{ml}$ of the same medium, containing various concentrations of labeled $\mathrm{E}^{-} / \mathrm{B}^{48}$ lipoproteins [very-low-density lipoprotein (VLDL)] for $2 \mathrm{~h}$ or containing $20 \mu \mathrm{g} / \mathrm{ml}$ labeled $\mathrm{E}^{-} / \mathrm{B}^{48}$ lipoproteins for $30,60,120$ and $240 \mathrm{~min}$. For the determination of surface bound proteins, the cells were pre-chilled on ice for $30 \mathrm{~min}$ before washing and incubating in medium containing $\mathrm{E}^{-/} \mathrm{B}^{48}$ lipoproteins; the cells were then incubated with $1 \mathrm{ml}$ of the same medium, containing various concentrations of labeled $\mathrm{E}^{-} / \mathrm{B}^{48}$ lipoproteins for $2 \mathrm{~h}$ or containing $20 \mu \mathrm{g} / \mathrm{ml}$ labeled $\mathrm{E}^{-} / \mathrm{B}^{48}$ lipoproteins for 30, 60, 120 and $240 \mathrm{~min}$. Following incubation with $\mathrm{E}^{-} / \mathrm{B}^{48}$ lipoproteins, the medium was removed and the cells were washed twice with $2 \mathrm{ml}$ of ice-cold PBS containing $0.2 \%$ BSA followed by 2 more washes with $2 \mathrm{ml}$ of ice-cold PBS. The cells were lysed by the addition of $1 \mathrm{ml}$ of $0.5 \mathrm{M} \mathrm{NaOH}$ and lysate was collected for the measurement of protein (10 $\mu \mathrm{l}$ of aliquot) and radioactivity taken up by the cells.

Endosomal fraction isolation. Mouse liver endosomal fractions were isolated as prevously described by Chen et al (23). Mouse livers were homogenized in $20 \%$ (w/v) homogenization buffer containing $0.25 \mathrm{M}$ sucrose, $3 \mathrm{mM}$ imidazole ( $\mathrm{pH}$ 7.4), $1.7 \mathrm{nM}$ antipain, $2 \mathrm{nM}$ leupeptin and $1 \mathrm{mM}$ phenylmethylsulfonyl fluoride. The homogenate was centrifuged at $460 \mathrm{x}$ g for $10 \mathrm{~min}$, the supernatant was saved and the pellet was rehomogenized and centrifuged as described above. The pooled supernatant was centrifuged at $24,000 \mathrm{x}$ g for $10 \mathrm{~min}$, and the resulting supernatant (S2) was then centrifuged at 100,000 x g for $90 \mathrm{~min}$. The resulting microsomal pellet (P3) was suspended in homogenization buffer (1.0 g starting liver/2 $\mathrm{ml}$ homogenization buffer) using 10 strokes at $1,000 \mathrm{rpm}$. The resuspended P3 was then diluted with an equal volume of $2.0 \mathrm{M}$ sucrose in $3 \mathrm{mM}$ imidazole buffer. Three milliliters aliquots of the resulting $1.15 \mathrm{M}$ sucrose fraction were successively overlaid with 1.0, 0.86, 0.6 and $0.25 \mathrm{M}$ sucrose solutions, all buffered with $3 \mathrm{mM}$ imidazole. Following centrifugation at 100,000 x g for $3.5 \mathrm{~h}, 3$ distinct fractions of average density 1.06, 1.09 and 
$1.12 \mathrm{~g} / \mathrm{ml}$ were obtained. The 1.06 and 1.09 fractions were pooled to yield the late endosomal fraction, and the $1.12 \mathrm{~g} / \mathrm{ml}$ fraction contained early endosomes.

Western blot analysis. Endosomal fractions were isolated and prepared as described above. Endosomal proteins were extracted by a dual precipitation procedure. First, endosomal fractions were suspended in $20 \%$ trichloroacetic acid (TCA) with $20 \mathrm{mM}$ DTT (1 g of starting liver/2 $\mathrm{ml} 20 \%$ TCA). Second, the suspension was allowed to precipitate on ice for $2 \mathrm{~h}$ and centrifuged at $1000 \mathrm{x}$ g for $10 \mathrm{~min}$, and the pellet was then suspended in acetone with $20 \mathrm{mM}$ DTT ( $1 \mathrm{~g}$ of starting liver $/ 2 \mathrm{ml}$ acetone). Proteins in the suspension were precipitated at $-20^{\circ} \mathrm{C}$ for $4 \mathrm{~h}$ and centrifuged at $1,000 \mathrm{x} \mathrm{g}$ for $5 \mathrm{~min}$. Residual acetone was removed by lyophilization. The protein pellet was solubilized in lysis buffer, sonicated at $100 \mathrm{~W}$ for $30 \mathrm{sec}$, and centrifuged at 25,000 $\mathrm{x} \mathrm{g}$ for $1 \mathrm{~h}$. Plasma membrane proteins were extracted using the Plasma Membrane Protein Extraction kit (Abcam, Cambridge, MA, USA). Nuclear and cytoplasmic proteins from the cells were extracted using the Nuclear-Cytosol Extraction kit (BioVision, Inc., Milpitas, USA). Protein expression was determined by western blot analysis. Briefly, equal amounts of protein were separated by 7.0 or $10 \%$ SDS-polyacrylamide gel electrophoresis (SDS-PAGE) and elcetrophoretically transferred onto nitrocellulose membranes. After being blocked with TBST containing 5\% bovine serum albumin, the membranes were incubated with primary antibodies against ATM (Santa Cruz Biotechnology, Inc., Santa Cruz, CA, USA) and phosphorylated ATM (p-ATM) protein (Cell Signaling Technology, Danvers, MA, USA) at $4^{\circ} \mathrm{C}$ overnight, followed by incubation with horseradish peroxidase-conjugated secondary antibody for $1 \mathrm{~h}$ at room temperature. The immunostaining was visualized by enhanced chemiluminescence, and the results were normalized to $\beta$-actin expression.

Co-immunoprecipitation. The hepatocytes were pre-treated with chloroquine (an ATM activator) for $1 \mathrm{~h}$ and then treated with $40 \mu \mathrm{g} / \mathrm{ml}$ lipoproteins for $8 \mathrm{~h}$. Cytoplasmic proteins $(500 \mu \mathrm{g})$ from the cells extracted using the Nuclear-Cytosol Extraction kit were used to perform immunoprecipitation assays according to the manufacturer's instructions (Pierce, Rockford, IL, USA). Briefly, the cytoplasmic lysates were incubated with ATM or class III PI3K antibody (Santa Cruz Biotechnology, Inc.) for $2 \mathrm{~h}$ at room temperature followed by the addition of protein $\mathrm{A} / \mathrm{G}-$ Sepharose beads and further overnight incubation at $4^{\circ} \mathrm{C}$ with gentle rocking. The immunoprecipitates were washed 3 times with lysis buffer. The samples were then subjected to SDS-PAGE and immunoblotting.

Class III PI3K activity assay. Cytoplasmic proteins from cells were extracted using the Nuclear-Cytosol Extraction kit (BioVision). The proteins were immunoprecipitated with anti-class $\mathrm{II}$ PI3K antibody for $2 \mathrm{~h}$ at room temperature, and subsequently incubated with A Sepharose beads overnight at $4^{\circ} \mathrm{C}$. The precipitates were then washed with lysis buffer. The immunoprecipitated proteins were incubated with PIP substrates in vitro, and the PI(3)P products were measured with the use of class III PI3K ELISA kit (Echelon Biosciences, Salt Lake City, UT, USA) according to the manufacturer's instructions.
Measurement of cellular cholesterol. Hepatocytes grown in 75-mm culture flasks were pre-treated with $5 \mu \mathrm{M}$ chloroquine, $10 \mu \mathrm{mol} / 1 \mathrm{KU} 55933$ (an ATM-specific inhibitor), $10 \mu \mathrm{M}$ LY290042 (a class III PI3K inhibitor) or 5 mM 3-MA (a class III PI3K inhibitor) for $2 \mathrm{~h}$ and then incubated with $40 \mu \mathrm{g}$ / $\mathrm{ml} \mathrm{E} / \mathrm{B}^{48}$ lipoproteins for $22 \mathrm{~h}$ followed by a 12 -h equilibrium in lipoprotein-free medium. Quantitative measurement of intracellular total cholesterol (TC) in vitro was analyzed using the method described in the study by Gamble et al (24). In brief, the hepatocytes were collected and lipids were extracted by the addition of chloroform:methanol (2:1). The lipid phase was collected, dried, and then dissolved in isopropanol containing $10 \%$ Triton X-100. The concentrations of TC were measured by enzymatic assays and normalized to total cellular protein levels.

Statistical analysis. The data are expressed as the means \pm SEM. Comparisons among multiple groups were performed using one-way ANOVA or two-way ANOVA followed by the StudentNewman-Keuls or Dunnett's test. Differences were considered significant at $\mathrm{P}<0.05$.

\section{Results}

Uptake of $E^{-/ B} B^{48}$ lipoproteins. Both $A T M^{+/-} / A_{p o E^{-/}}$and $A T M^{+/+}$ $A p o E^{-/-}$hepatocytes absorbed $\mathrm{E}^{-/} \mathrm{B}^{48}$ lipoproteins in a concentration and time-dependent manner. However, the uptake of $\mathrm{E}^{-} / \mathrm{B}^{48}$ lipoproteins by the $A T M^{+/+} / A p o E^{-/-}$hepatocytes was greater than that of the $A T M^{+/ /} / A p o E^{-/-}$hepatocytes. The uptake of $\mathrm{E}^{-/} \mathrm{B}^{48}$ lipoproteins by the $A T M^{+/+} / A p o E^{-/-}$hepatocytes was greater by 38-65\% compared with the $A T M^{+/ /} / A p o E^{-/-}$hepatocytes at the concentration range of $5-40 \mu \mathrm{g} / \mathrm{ml}$; in particular, a significant difference was observed between the $A T M^{+/-}$ $\mathrm{ApoE}^{-/-}$and $\mathrm{ATM}^{+/+} / \mathrm{ApoE}^{-/-}$hepatocytes at the concentration range of $20-40 \mu \mathrm{g} / \mathrm{ml}$ and at the 120 and $240 \mathrm{~min}$ time points $(\mathrm{P}<0.05)$ (Fig. 1).

Binding of $E^{-/} B^{48}$ lipoproteins. Both $A T M^{+/ /} / A p o E^{-/-}$and $A T M^{+/+} / A_{p o E^{-/}}$hepatocytes bound $\mathrm{E}^{-} / \mathrm{B}^{48}$ lipoproteins in a concentration-dependent manner. However, no significant difference was observed in the binding of $\mathrm{E}^{-} / \mathrm{B}^{48}$ lipoproteins to the $A T M^{+/ /} / A p o E^{-/-}$and $A T M^{+/+} / A p o E^{-/-}$hepatocytes at the concentration range of 5-40 $\mu \mathrm{g} / \mathrm{ml}$ (Fig. 2A). The binding of $\mathrm{E}^{-/} / \mathrm{B}^{48}$ lipoproteins to the $A T M^{+/-} / \mathrm{ApoE}^{-/-}$and $A T M^{+/+} / \mathrm{ApoE}^{-/-}$ hepatocytes was not enhanced and no significant difference was observed as time progressed (Fig. 2B).

Distribution of ATM protein in endosomes and ATM activation by chloroquine in the nucleus and cytoplasm. ATM protein and p-ATM protein were expressed in the nucleus, early endosomes and late endosomes, but not in the plasma membrane in the hepatocytes of $A p o E^{-/-}$mice (Fig. 3). The hepatocytes of $A p o E^{-/-}$mice were incubated with various concentrations of chloroquine $(0,5$ and $10 \mu \mathrm{mol} / \mathrm{l})$ for $8 \mathrm{~h}$ at $37^{\circ} \mathrm{C}$. p-ATM levels in the nucleus and cytoplasm increased following treatment with chloroquine in a dose-dependent manner $(\mathrm{P}<0.05)$ (Fig. 4).

ATM protein interaction with class III PI3K protein and its effect on class III PI3K activity. As ATM has been shown to 


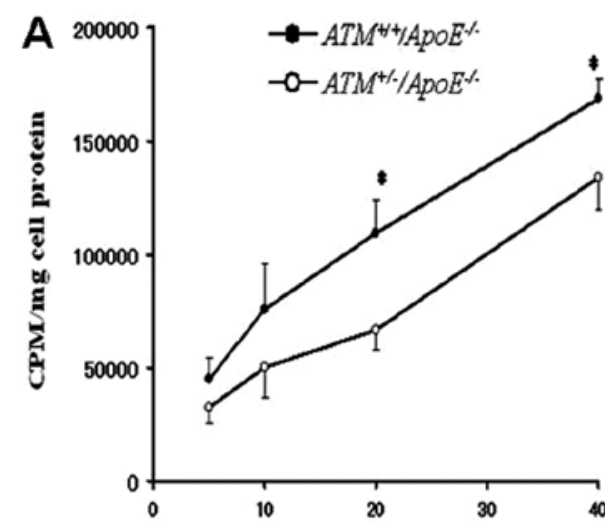

Concentration of VLDL $(\mu \mathrm{g} / \mathrm{ml})$

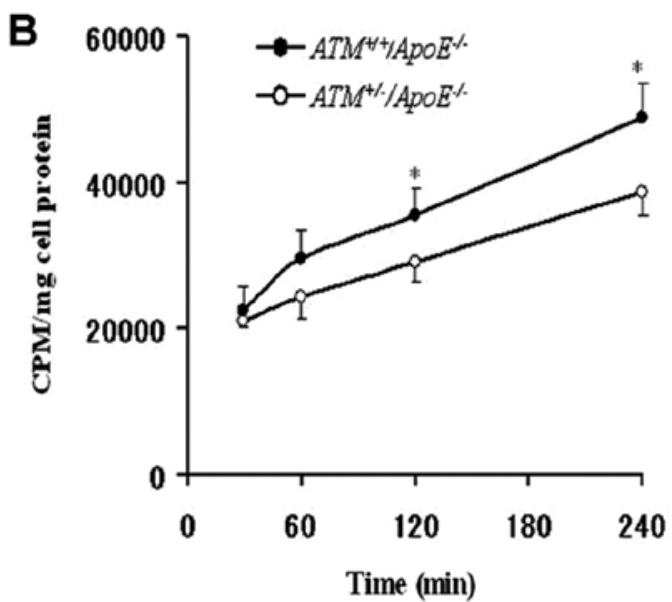

Figure 1. Uptake of ${ }^{125} \mathrm{I}$-labeled apolipoprotein (Apo)E-deficient, ApoB48-containing $\left(\mathrm{E}^{-} / \mathrm{B}^{48}\right)$ lipoproteins by hepatocytes. Hepatocytes were isolated from ataxia telangiectasia mutated $(A T M)^{+/-} / \mathrm{ApoE}^{-/-}$and $A T M^{+/} / A p o E^{-/-}$mice by perfusion of the portal vein and incubated $(\mathrm{A})$ with various concentrations of $\mathrm{E}^{-/} \mathrm{B}^{48}$ lipoproteins for $2 \mathrm{~h}$ and $(\mathrm{B})$ with $20 \mu \mathrm{g} / \mathrm{ml}$ of $\mathrm{E}^{-} / \mathrm{B}^{48}$ lipoproteins for different periods of time at $37^{\circ} \mathrm{C}$. The radioactivity in the cell lysates was measured as described in Materials and methods. Values represent the means $\pm \mathrm{SEM}$ of 5 mice. *Significant difference compared to $A T M{ }^{+/-} / A_{p o E^{-/}}$mice $(\mathrm{P}<0.05)$. VLDL, very-low-density lipoprotein.

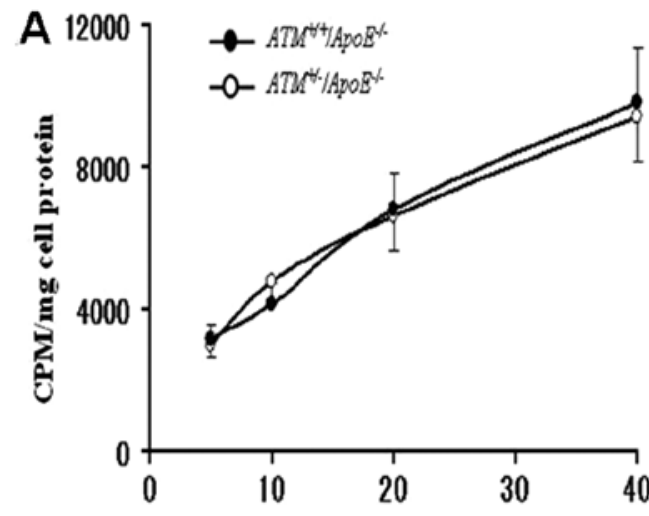

Concentration of VLDL $(\mu \mathrm{g} / \mathrm{ml})$

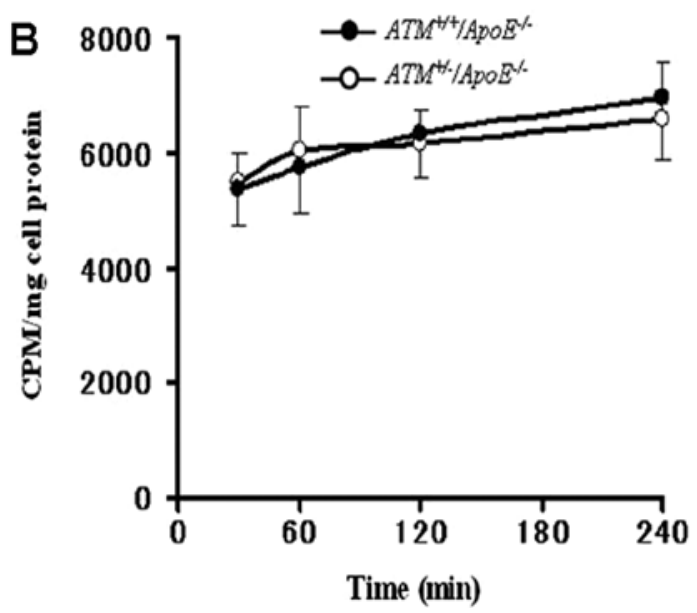

Figure 2. Binding of ${ }^{125} \mathrm{I}$-labeled apolipoprotein (Apo)E-deficient, ApoB48-containing ( $\mathrm{E}^{-/} \mathrm{B}^{48}$ ) lipoproteins to hepatocytes. Hepatocytes were isolated from ataxia telangiectasia mutated $(A T M)^{+/-} / A p o E^{-/-}$and $A T M^{+/+} / A p o E^{-/-}$mice by perfusion of the portal vein and incubated $(\mathrm{A})$ with various concentrations of $\mathrm{E}^{-/} / \mathrm{B}^{48}$ lipoproteins for $2 \mathrm{~h}$ and (B) with $20 \mu \mathrm{g} / \mathrm{ml}$ of $\mathrm{E}^{-} / \mathrm{B}^{48}$ lipoproteins for different periods of time at $4^{\circ} \mathrm{C}$. The radioactivity in the cell lysates was measured as described in Materials and methods. Values represent the means \pm SEM of 5 mice. VLDL, very-low-density lipoprotein.

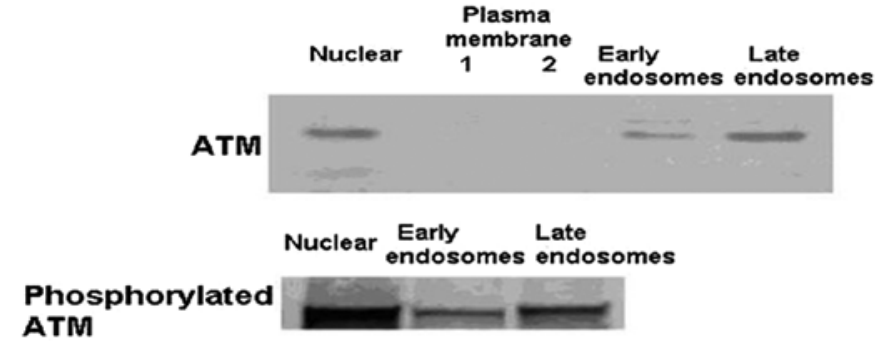

Figure 3. Ataxia telangiectasia mutated (ATM) and phosphorylated ATM protein in early and late endosomes in apolipoprotein (Apo)E-deficient $\left(\mathrm{ApoE}^{-/-}\right)$ mice. Early endosomes $(\mathrm{d}=1.12 \mathrm{~g} / \mathrm{ml})$, late endosomes $(\mathrm{d}=1.06-1.09 \mathrm{~g} / \mathrm{ml})$ and cell nuclei were isolated by density ultracentrifugation. Plasma membrane proteins were extracted using the Plasma Membrane Protein Extraction kit. Nuclear proteins were extracted using the Nuclear-Cytosol Extraction kit. ATM and phosphorylated ATM protein expression was measured by western blot analysis as described in Materials and methods $(n=3)$. possess a carboxyl-terminal domain homologous to PI3Ks and that ATM protein regulate PI3K activitys, we wished to determine whether ATM interacts with class III PI3Ks and whether ATM activation affects the activity of class III PI3Ks. The results from co-immunoprecipitation analysis indicated that cytoplasmic ATM protein interacted with cytoplasmic class III PI3K protein (Fig. 5A). In addition, when the hepatocytes were incubated with $\mathrm{E}^{-} / \mathrm{B}^{48}$ lipoproteins alone, class III PI3K protein activity increased; however, no significant difference was observed between the control group (untreated group) and the group treated with $\mathrm{E}^{-} / \mathrm{B}^{48}$ lipoproteins $(\mathrm{P}>0.05)$. When the hepatocytes incubated with $\mathrm{E}^{-} / \mathrm{B}^{48}$ lipoproteins and chloroquine, class III PI3K activity markedly increased $(\mathrm{P}<0.01)$; however, this effect was attenuated by the ATM inhibitor, KU55933 (P<0.05) (Fig. 5B). 
A

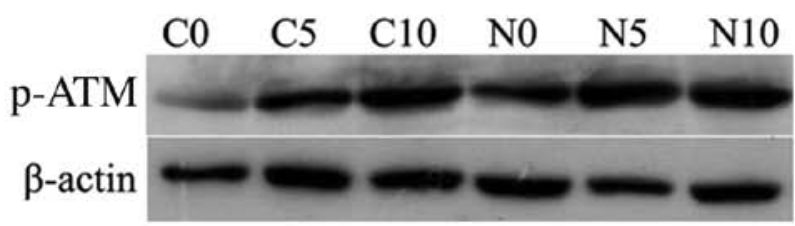

B

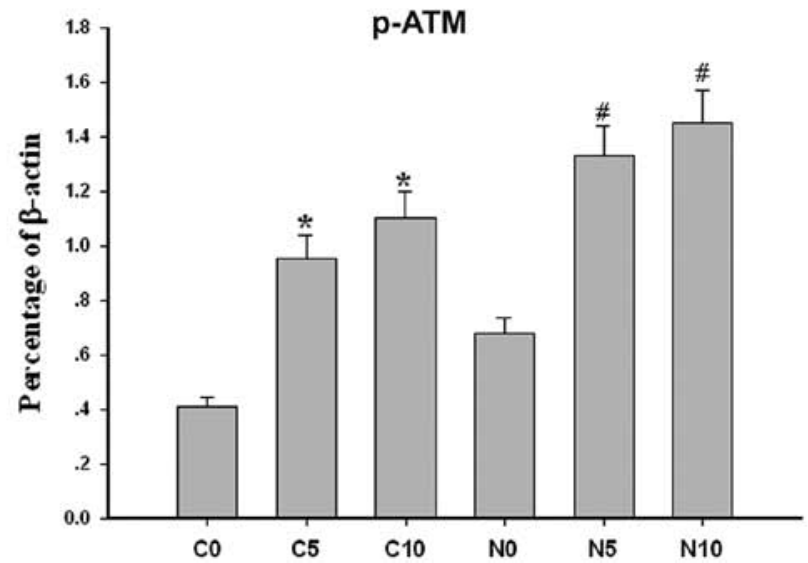

Figure 4. Ataxia telangiectasia mutated (ATM) activation by chloroquine in the nucleus and cytoplasm. (A) Representative protein bands from western blot analysis for phosphorylated ATM (p-ATM) and $\beta$-actin. (B) The intensity of the p-ATM band was quantified and the ratio of p-ATM to $\beta$-actin was calculated. Hepatocytes were isolated from apolipoprotein (Apo)E-deficient $\left(A p o E^{-/ /}\right)$mice by perfusion of the portal vein and incubated with various concentrations of chloroquine $(0,5$ and $10 \mu \mathrm{mol} / \mathrm{l})$ for $8 \mathrm{~h}$ at $37^{\circ} \mathrm{C}$. ' $\mathrm{C}$ ' indicates that the protein was from the cytoplasm. ' $\mathrm{N}$ ' indicates that the protein was from the nucleus; 0 , untreated group; $5,5 \mu \mathrm{mol} / 1$ cholrquine-treated group; $10,10 \mu \mathrm{mol} / 1$ chloroquine-treated group. Results are expressed as the means $\pm \mathrm{SEM}(\mathrm{n}=5)$. ${ }^{\sharp} \mathrm{P}<0.05 \mathrm{vs}$. N0 group; ${ }^{*} \mathrm{P}<0.05$ vs. $\mathrm{C} 0$ group.

\section{A Class III PI3K ATM}

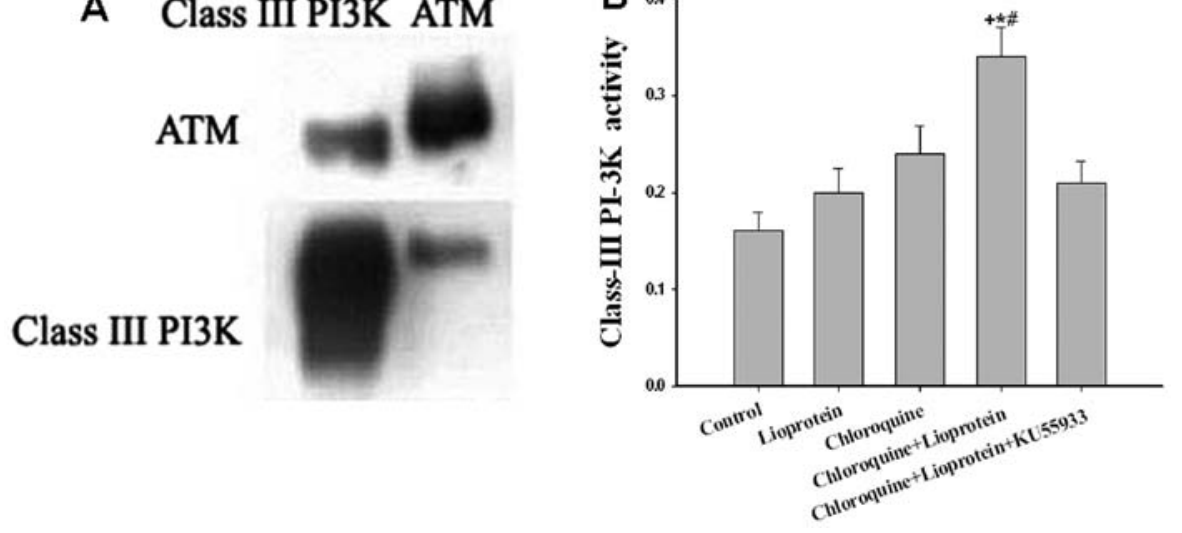

Figure 5. Analysis of the interaction betweetn ataxia telangiectasia mutated (ATM) and class II phosphatidylinositol-3-kinases (PI3Ks) by co-immunoprecipitation and augmentation of class $\mathrm{WI}$ PI3K activity induced by the activation of ATM protein by chloroquine. (A) Representative protein bands from co-immunoprecipitation analysis between and ATM and class III PI3K protein. Hepatocytes from apolipoprotein (Apo)E-deficient mice (ApoE $E^{-/}$mice) were pre-treated with $5 \mu \mathrm{mol} / 1$ chloroquine for $1 \mathrm{~h}$ and then treated with $40 \mu \mathrm{g} / \mathrm{ml} \mathrm{ApoE-deficient,} \mathrm{ApoB} 48$-containing $\left(\mathrm{E}^{-} / \mathrm{B}^{48}\right)$ lipoproteins for $8 \mathrm{~h}$ at $37^{\circ} \mathrm{C}$. Cells were collected and homogenated. Protein in the cytoplasm was extracted and immunoprecipitated with ATM and class III PI3K proteins. Western blot analysis was performed to determine whether the immunoprecipitates contained ATM and class WI PI3K proteins. (B) Class WI PI3K activity was assessed by ELISA. Hepatocytes from $A p o E^{-/-}$mice were incubated with $5 \mu \mathrm{mol} / 1$ chloroquine, $40 \mu \mathrm{g} / \mathrm{ml} \mathrm{E} / \mathrm{B}^{48}$ lipoproteins and $10 \mu \mathrm{mol} / 1 \mathrm{KU} 55933$ (an ATM inhibitor) for $8 \mathrm{~h}$ at $37^{\circ} \mathrm{C}$. Cells were collected and centrifuged. Cytoplasmic proteins from the cells were extracted using the Nuclear-Cytosol Extraction kit. Class $\amalg$ PI $3 \mathrm{~K}$ protein in the cytoplasm was immunoprecipitated, and then its activity was determined using the class WI PI3K activity ELISA kit. Values represent the means \pm SEM of 5 mice. ${ }^{*} \mathrm{P}<0.05$ vs. control; ${ }^{*} \mathrm{P}<0.05$ vs. lipoprotein; ${ }^{+} \mathrm{P}<0.05$ vs. chloroquine + lipoprotein + KU55933.

Class III PI3K inhibitor attenuates intracellular total cholesterol accumulation induced by ATM activation. When the hepatocytes were incubated with $\mathrm{E}^{-} / \mathrm{B}^{48}$ lipoproteins alone, the intracellular total cholesterol of the hepatocytes increased, compared with the control (untreated) group $(653.8 \pm 58.2$ vs. $362.5 \pm 38.2 \mathrm{mg} / \mathrm{g}$ protein). When the hepatocytes were incubated with $\mathrm{E}^{-} / \mathrm{B}^{48}$ lipoproteins and chloroquine, the intracellular total cholesterol of the hepatocytes markedly increased compared with the lipoprotein-treated group (1038.5 \pm 88.3 vs. $653.8 \pm 58.2 \mathrm{mg} / \mathrm{g}$ protein). However, treatment with the ATM inhibitor, KU55933, and the class III PI3K inhibitor, LY290042 and 3-MA, abolished the intracellular total cholesterol accumulation induced by chloroquine $(702.8 \pm 78.6$ vs .
$1038.5 \pm 88.3 \mathrm{mg} / \mathrm{g}$ protein), $(753.3 \pm 82.5$ vs. $1038.5 \pm 88.3 \mathrm{mg} / \mathrm{g}$ protein) or (732.2 \pm 76.3 vs. $1038.5 \pm 88.3 \mathrm{mg} / \mathrm{g}$ protein), respectively (Fig. 6).

\section{Discussion}

The major findings of the present study are as follows: i) the uptake of $\mathrm{E}^{-} / \mathrm{B}^{48}$ lipoproteins by the $A T M^{+/+} / A{ }^{2} E^{-/-}$hepatocytes was greater than that of the $A T M^{+/-} / A p o E^{-/ /}$hepatocytes, although no significant difference was observed in the binding of $\mathrm{E}^{-/} \mathrm{B}^{48}$ lipoproteins between the $A T M^{+/+} / \mathrm{ApoE}^{-/ /}$and $A T M^{+/-} /$ $A p o E^{-/-}$hepatocytes; ii) a fraction of the ATM protein was expressed in early endosomes and late endosomes, but not in the 


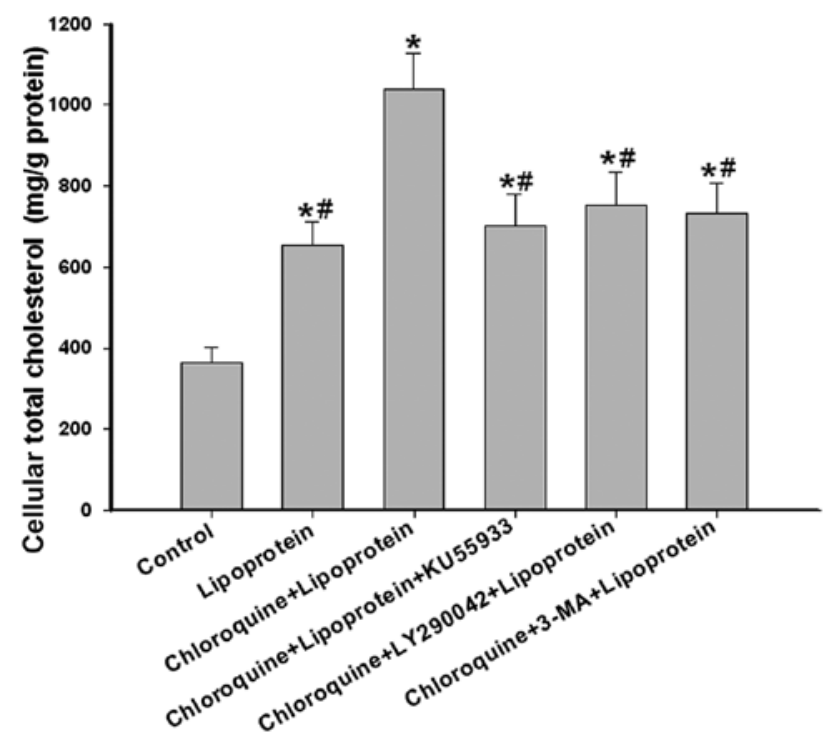

Figure 6. Class III phosphatidylinositol-3-kinase (PI3K) inhibitor attenuates intracellular total cholesterol accumulation induced by ataxia telangiectasia mutated (ATM) activation. Hepatocytes were isolated from apolipoprotein (Apo)E-deficient mice (ApoE $E^{-/-}$mice) by perfusion of the portal vein and pretreated with $5 \mu \mathrm{M}$ chloroquine, $10 \mu \mathrm{mol} / 1 \mathrm{KU} 55933$ (an ATM inhibitor), $10 \mu \mathrm{M}$ LY290042 (a class III PI3K inhibitor) or 5 mM 3-MA (a class III PI3K inhibitor) for $2 \mathrm{~h}$ and then incubated with $40 \mu \mathrm{g} / \mathrm{ml}$ ApoE-deficient, ApoB48-containing $\left(\mathrm{E}^{-} / \mathrm{B}^{48}\right)$ lipoproteins for $22 \mathrm{~h}$ at $37^{\circ} \mathrm{C}$. Cellular total cholesterol in hepatocytes was determined using an enzymatic kit. Values represent the means \pm SEM of 8 mice. ${ }^{*} \mathrm{P}<0.05$ vs. control; ${ }^{\#} \mathrm{P}<0.05$ vs. choroquine + lipoprotein.

plasma membrane; iii) ATM protein interacted with class III PI3K protein and the activated ATM protein enhanced class III PI3K activity; iv) the class III PI3K inhibitor, LY290042, abolished the intracellular total cholesterol accumulation induced by ATM activation.

Under physiological conditions, ApoE activates receptormediated endocytosis by binding to cell surface low-density lipoprotein (LDL) receptor and LDL receptor-related protein (LRP) (25). The deletion of ApoE, lipoproteins containing ApoB100 (such as LDL) can still be achieved by the interaction between ApoB100 and LDL receptor, but lipoproteins containing ApoB48 can not enter cells through the LDL receptor and LRP (26). We previously reported that ATM heterozygous mutation in $A p o E^{-/-}$mice resulted in an overaccumulation of plasma ApoB48-containing lipoproteins and severe hypercholesterolemia occurred only with a combination of a heterozygous ATM mutation and a null ApoE mutation, but not wih the heterozygous $A T M$ mutation alone or with the combined heterozygous $A T M$ and null $L D L$ receptor mutations (7). The present experimental results revealed that despite the lack of ApoE, lipoproteins containing ApoB48 can still be absorbed. Compared with hepatocytes of $A T M^{+/+} / A p o E^{-/-}$mice, the uptake of $\mathrm{E}^{-/} \mathrm{B}^{48}$ lipoproteins by hepatocytes of $A T M^{+/-} / A p o E^{-/-}$mice decreased significantly; however, no signficant difference was observed in the binding of $\mathrm{E}^{-} / \mathrm{B}^{48}$ lipoproteins between hepatocytes from $A T M^{+/+} / A p o E^{-/-}$mice and those of $A T M^{+/ /}$ $A p o E^{-/-}$mice. Based on these results, it can be concluded that there are other pathways mediating the endocytosis of lipoproteins containing ApoB48 without ApoE, and ATM facilitates the endocytosis of lipoproteins containing ApoB48. In addition, we found that a portion of the ATM protein was localized in early endosomes and late endosomes, but not in the plasma membrane. These results indicate that the ATM protein may participate in the endocytosis of $\mathrm{E}^{-} / \mathrm{B}^{48}$ lipoproteins.

Since we observed that the ATM protein was expressed in endosomes and it is known that class III PI3Ks are responsible for the production of PtdIns(3)P in the membranes of endosomes, and mediate vesicular transport, membrane trafficking and intracellular protein sorting $(14,27,28)$, our study focused on the effects of ATM on the activity of class III PI3Ks. Certain studies have reported that small doses of chloroquine activate nucleic ATM proteins (29). In this study, we observed that chloroquine activated ATM in the nucleus and cytoplasm of hepatocytes in a dose-dependent manner. ATM has been shown to possess a carboxyl-terminal domain homologous to PI3Ks and ATM protein has been shown to interact with PI3K, regulating PI3K activity $(21,22)$. Similar to this result, in our present study, we observed an interaction between cytoplasmic ATM and class III PI3Ks; activated ATM increased class III PI3K protein activity. Moreover, chloroquine, which activated ATM protein, promoted intracellular total cholesterol accumulation, while the class III PI3K inhibitor, LY290042 and 3-MA, inhibited this effect, suggesting that class III PI3K protein plays an important role in the ATM protein-mediated endocytosis of $\mathrm{E}^{-} / \mathrm{B}^{48}$ lipoproteins in the hepatocytes of $A p o E^{-/-}$ mice.

Previous studies have confirmed that there are ApoEindependent mechanisms which mediate the uptake of lipoproteins containing ApoB48. Magoori et al (30) reported that $A p o E$ and $L R P-5$ double knockout mice developed more severe hypercholesterolemia than $A p o E^{-/-}$mice and that this hypercholesterolemia resulted mainly from an increased level of ApoB-48-containing lipoproteins in the plasma, wheras LRP-5 single knockout mice showed no significant difference in plasma cholesterol levels. These results indicate that the LRP-5 mediates the ApoE-independent plasma lipoprotein metabolism pathway. Therefore, it is possible that $\mathrm{E}^{-} / \mathrm{B}^{48}$ lipoproteins interact with cell membrane receptors, such as LRP-5 through unknown mechanisms, and may activate cytosolic ATM; activated ATM in turn activates class III PI3K, regulating the endocytosis of $\mathrm{E}^{-} / \mathrm{B}^{48}$ lipoproteins. This may facilitate $\mathrm{E}^{-/} / \mathrm{B}^{48}$ lipoprotein degradation and metabolism. Based on these results, we hypothesized that the ATM/class III PI3K pathway may be involved in the endocytosis of $\mathrm{E}^{-/} / \mathrm{B}^{48}$ lipoproteins. In addition, it is evident that chloroquine exerts an inhibitory effect on blood lipids; however, the exact mechanisms involved are unclear. Our results suggest that the decrease in blood lipid levels by chloroquine may be associated with the activation of the ATM/class III PI3K pathway, thus promoting the uptake of lipoproteins by hepatocytes.

In conclusion, to the best of our knowledge, the results presented in this study demonstrate for the first time that a heterozygous mutation in $A T M$ reduces the uptake of $\mathrm{E}^{-/} \mathrm{B}^{48}$ lipoproteins by hepatocytes of $A p o E^{-/-}$mice. We also found that ATM was distributed in early endosomes and late endosomes. Our results demonstrated that the ATM protein interacted with class III PI3K protein and the activated ATM protein enhanced class III PI3K activity. In addition, the ATM activation promoted intracellular total cholesterol accumulation; however, this was abolished by the class III PI3K inhibitor, LY290042. These observations suggest that ATM is involved 
in the endocytosis of $\mathrm{E}^{-/} / \mathrm{B}^{48}$ lipoproteins through the class III PI3K protein. Our findings provide further insight into the mechanisms through which the ATM activation by chloroquine exerts beneficial effects, reducing blood lipid levels.

\section{Acknowledgements}

This study was supported by a grant from the National Nature Science Foundation of China (30971428 to D.W.).

\section{References}

1. Frappart PO and McKinnon PJ: Ataxia-telangiectasia and related diseases. Neuromolecular Med 8: 495-511, 2006.

2. Lavin MF: ATM: the product of the gene mutated in ataxiatelangiectasia. Int J Biochem Cell Biol 31: 735-740, 1999.

3. Badalian LO and Kalinina LV: Lipid metabolism disorder in ataxia-telangiectasia. Zh Nevropatol Psikhiatr Im S S Korsakova 76: 665-669, 1976 (In Russian).

4. Su Y and Swift M: Mortality rates among carriers of ataxiatelangiectasia mutant alleles. Ann Intern Med 133: 770-778, 2000 .

5. Schneider JG, Finck BN, Ren J, et al: ATM-dependent suppression of stress signaling reduces vascular disease in metabolic syndrome. Cell Metab 4: 377-389, 2006.

6. Mercer JR, Cheng KK, Figg N, et al: DNA damage links mitochondrial dysfunction to atherosclerosis and the metabolic syndrome. Circ Res 107: 1021-1031, 2010.

7. Wu D, Yang H, Xiang W, et al: Heterozygous mutation of ataxiatelangiectasia mutated gene aggravates hypercholesterolemia in apoE-deficient mice. J Lipid Res 46: 1380-1387, 2005.

8. Watters D, Kedar P, Spring K, et al: Localization of a portion of extranuclear ATM to peroxisomes. J Biol Chem 274: 34277-34282, 1999.

9. Kuljis RO, Chen G, Lee EY, Aguila MC and Xu Y: ATM immunolocalization in mouse neuronal endosomes: implications for ataxia-telangiectasia. Brain Res 842: 351-358, 1999.

10. Barlow C, Ribaut-Barassin C, Zwingman TA, et al: ATM is a cytoplasmic protein in mouse brain required to prevent lysosomal accumulation. Proc Natl Acad Sci USA 97: 871-876, 2000.

11. Lim DS, Kirsch DG, Canman CE, et al: ATM binds to betaadaptin in cytoplasmic vesicles. Proc Natl Acad Sci USA 95: 10146-10151, 1998.

12. Engelman JA, Luo J and Cantley LC: The evolution of phosphatidylinositol 3-kinases as regulators of growth and metabolism. Nat Rev Genet 7: 606-619, 2006.

13. Backer JM: Phosphoinositide 3-kinases and the regulation of vesicular trafficking. Mol Cell Biol Res Commun 3: 193-204, 2000.

14. Hunyady L, Baukal AJ, Gaborik Z, et al: Differential PI 3-kinase dependence of early and late phases of recycling of the internalized AT1 angiotensin receptor. J Cell Biol 157: 1211-1222, 2002.
15. Lemmon MA: Phosphoinositide recognition domains. Traffic 4: 201-213, 2003

16. Gillooly DJ, Morrow IC, Lindsay M, et al: Localization of phosphatidylinositol 3-phosphate in yeast and mammalian cells. EMBO J 19: 4577-4588, 2000.

17. Kutateladze TG: Phosphatidylinositol 3-phosphate recognition and membrane docking by the FYVE domain. Biochim Biophys Acta 1761: 868-877, 2006.

18. Choi JH, Hong WP, Kim MJ, Kim JH, Ryu SH and Suh PG: Sorting nexin 16 regulates EGF receptor trafficking by phosphatidylinositol-3-phosphate interaction with the Phox domain. J Cell Sci 117: 4209-4218, 2004.

19. Shetty S, Eckhardt ER, Post SR and van der Westhuyzen DR: Phosphatidylinositol-3-kinase regulates scavenger receptor class B type I subcellular localization and selective lipid uptake in hepatocytes. Arterioscler Thromb Vasc Biol 26: 2125-2131, 2006.

20. Kzhyshkowska J, Gratchev A, Brundiers H, Mamidi S, Krusell L and Goerdt S: Phosphatidylinositide 3-kinase activity is required for stabilin-1-mediated endosomal transport of acLDL. Immunobiology 210: 161-173, 2005.

21. Lavin MF, Khanna KK, Beamish H, Spring K, Watters D and Shiloh Y: Relationship of the ataxia-telangiectasia protein ATM to phosphoinositide 3-kinase. Trends Biochem Sci 20: 382-383, 1995.

22. Khanna KK, Yan J, Watters D, et al: Defective signaling through the B cell antigen receptor in Epstein-Barr virus-transformed ataxia-telangiectasia cells. J Biol Chem 272: 9489-9495, 1997.

23. Chen A, Guo Z, Zhou L and Yang H: Hepatic endosome protein profiling in apolipoprotein $\mathrm{E}$ deficient mice expressing apolipoprotein B48 but not B100. J Bioanal Biomed 2: 100-106, 2010.

24. Gamble W, Vaughan M, Kruth HS and Avigan J: Procedure for determination of free and total cholesterol in micro- or nanogram amounts suitable for studies with cultured cells. J Lipid Res 19: 1068-1070, 1978

25. Martins IJ,Hone E, Chi C, Seydel U, Martins RN and Redgrave TG: Relative roles of LDLr and LRP in the metabolism of chylomicron remnants in genetically manipulated mice. J Lipid Res 41: 205-213, 2000.

26. Hui DY, Innerarity TL, Milne RW, Marcel YL and Mahley RW: Binding of chylomicron remnants and beta-very low density lipoproteins to hepatic and extrahepatic lipoprotein receptors. A process independent of apolipoprotein B48. J Biol Chem 259: 15060-15068, 1984.

27. Corvera S: Phosphatidylinositol 3-kinase and the control of endosome dynamics: new players defined by structural motifs. Traffic 2: 859-866, 2001.

28. Clague MJ, Urbé S and de Lartigue J: Phosphoinositides and the endocytic pathway. Exp Cell Res 315: 1627-1631, 2009.

29. Bakkenist CJ and Kastan MB: DNA damage activates ATM through intermolecular autophosphorylation and dimer dissociation. Nature 421: 499-506, 2003.

30. Magoori K, Kang MJ, Ito MR, et al: Severe hypercholesterolemia, impaired fat tolerance, and advanced atherosclerosis in mice lacking both low density lipoprotein receptor-related protein 5 and apolipoprotein E. J Biol Chem 278: 11331-11336, 2003. 